\title{
Autonomous medication management group in a psychosocial care center: participants' experience
}

Grupo de gestão autónoma da medicação num centro de atenção psicossocial: experiência de usuários

Grupo de gestión autónoma de la medicación en un centro de atención psicosocial: experiencia de los usuarios

Caroline Poletto Favero* ${ }^{D}$; Jeferson Rodrigues**iD; Ingrid Pires Silva***iD;

Deivisson Vianna Dantas dos Santos**** (D); Tereza Maria Mendes Diniz de Andrade Barroso***** (D);

Sarah Soares Barbosa ${ }^{* * * * * *}$ (D); Sabrina Stefanello

\section{Abstract}

Background: Autonomous Medication Management Group (GGAM) is a group approach for users of psychiatric drugs to share experiences so that they can be protagonists and co-responsible for the decisions relating to their treatment.

Objective: To describe the experience of the participants of the GGAM in a psychosocial care center in Brazil.

Methodology: The study is qualitative, exploratory, and descriptive, using the structured interview method whose analysis followed the theoretical framework proposed by Minayo. The multidisciplinary team indicated 6 users with a mental disorder, who were prescribed psychotropic drugs for more than 6 months and who participated in the GGAM.

Results: Categories emerged such as Context, Experience, and Effects of the experience of participants in the GGAM. The description of their experiences showed that the group is regarded as a space for talking and listening.

Conclusion: The participation in the GGAM provided increased knowledge about psychiatric medication, help in dealing with treatment, strengthened relationships, protagonism and autonomy, and contribution to the appropriateness of the singular therapeutic project.

Keywords: mental health; personal autonomy; mental health services; psychotropic substances

\section{Resumo}

Enquadramento: Grupo de gestão autónoma da medicação (GGAM) é uma abordagem em grupo com usuários de medicação psiquiátrica que partilham experiências, no qual o usuário é protagonista e corresponsável pelas decisóes relacionadas com o seu tratamento.

Objetivo: Descrever a experiência dos usuários participantes do GGAM de um Centro de atenção psicossocial no Brasil. Metodologia: O estudo é qualitativo, exploratório e descritivo, com recurso à entrevista semiestruturada em que a análise seguiu o referencial teórico proposto por $\mathrm{Mi}$ nayo. Foram indicados 6 usuários pela equipa multiprofissional que possuem transtorno mental com prescrição de psicofármacos há mais de 6 meses e que participaram no GGAM.

Resultados: Emergiram como categorias o Contexto, a Experiência e os Efeitos da vivência dos usuários no GGAM. A descrição das experiências dos usuários mostrou o reconhecimento do grupo como um espaço de fala e escuta.

Conclusão: A participaçáo no GGAM proporcionou ampliação do conhecimento relativo à medicação psiquiátrica, à sua relação com o tratamento, fortalecimento das relaçóes, do protagonismo e autonomia e contribuição na apropriação sobre o projeto terapêutico singular.

Palavras-chave: saúde mental; autonomia pessoal; serviços de saúde mental; psicotrópicos

*BSc., RN, Santa Catarina State University, 88036-700, Florianópolis, Brazil [caarolfavero@gmail.com].(1) https://orcid.org/0000-0001-9046-3866. Contribution to the article: main research author Address for correspondence: Rua Protenor Vidal, 73 article: main research author. Address for

**ant.D. RN Universidade Federal de Santa Catarina 88040-970, Florianópolis, Brazil [jef rod@hotmail.com].(D) https://orcid.org/0000-0002-8612-9088. Contribution to the article: research guidance.

the article: research guidance. nópolis, Brasil finoridzimbaps@ hotmai CAPS II Ponta do Coral, 8800-400, Hioriznopolis, Brasilingridzimbaps@ hotmail.com]. (B) https://orcid.

*327. Contribution to the article: data production and analysis. vianna@omailcom]. article: research co-guidance.

article: research co-guidance.

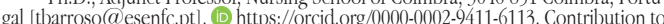
the article: data production and analysis.

the article: data production and analysis. rah.b@globo.com]. (1) https://orcid.org/0000-0002-6847-3942. Contribution to the article: data production and analysis.

article: data production and analysis.

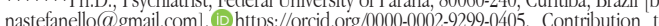
the article: data production and analysis.

\section{Resumen}

Marco contextual: El grupo de gestión autónoma de la medicación (GGAM) es un enfoque en grupo con usuarios de medicación psiquiátrica que comparten experiencias y en el cual el usuario es protagonista y corresponsable de las decisiones relacionadas con su tratamiento. Objetivo: Describir la experiencia de los usuarios que participan en el GGAM de un centro de atención psicosocial en Brasil.

Metodología: El estudio es cualitativo, exploratorio y descriptivo, se recurrió a la entrevista semiestructurada y el análisis siguió el referente teórico propuesto por Minayo. El equipo multiprofesional indicó 6 usuarios que tienen trastorno mental con prescripción de psicofármacos hace más de 6 meses y que participaron en el GGAM.

Resultados: Surgieron como categorías el contexto, la experiencia y los efectos de la experiencia de los usuarios en el GGAM. La descripción de las experiencias de los usuarios mostró el reconocimiento del grupo como un espacio para hablar y escuchar.

Conclusión: La participación en el GGAM amplió el conocimiento relativo a la medicación psiquiátrica, a su relación con el tratamiento, fortaleció las relaciones, el protagonismo y la autonomía, y contribuyó a la apropiación sobre este proyecto terapéutico singular.

Palabras clave: salud mental; autonomía personal; servicios de salud mental; psicotrópicos 


\section{Introduction}

Autonomous Medication Management (GAM) is the result of the fact that individuals participate little in decisions concerning their health care, thus limiting their attention, sometimes, only to symptoms and malaise. Due to this restricted involvement, they have lower critical ability about treatment choices and their bargaining power with health professionals, who consequently are the only ones making decisions (Onocko Campos et al., 2008).

Furthermore, even with the advancing arrangements in mental health, we note that pharmacological treatment is dominant in the actions of mental health professionals, to such an extent that, sometimes, mental health treatment is limited only to psychotropic substances. Barrio et al. (2014) emphasize that medicalization remains an unreformed practice not only in Brazil but also in other developed countries. Hospitalization and prescription renewal without the in-person assessment of users are still common responses to the demands of the health care system. Also, the users of this system feel they have no say in the crucial decision whether or not to initiate a drug treatment. Regarding new forms of care, one must bear in mind the complexity of the health-disease process as a guiding principle of practices. Also, the idea that medication is the main treatment route must be overcome. Therefore, it is necessary to broaden the dialogue between the different fields of knowledge, to incorporate work processes which increase the individuals' bargaining power, and to create horizontal relationships, aiming at the active participation of individuals in their treatment (Yasui \& Costa-Rosa, 2008).

\section{Background}

In Canada, in the 1990s, new mental health practices, like GAM, were created as a response to the reality of individuals' low participation in the decision of their drug treatments, but this process occurred in stages. The Regroupement des Ressources Alternatives en Santé Mentale du Québec, along with researchers from the Mental Health and Culture Research and Action Team (ÉRASME), began a research and experience process, which aimed to create opportunities for discussion on the role of medication in people's lives, its role in professional practices, and its involvement in society as a whole (Onocko Campos et al., 2008).

In Brazil, the psychiatric reform faces the challenge of modifying the context of the use of psychiatric medication with little criticism. One way to deal with this obstacle would be to increase the individuals' bargaining power over their treatment, by promoting their dialogue with health professionals about the role that medication plays in their life when considering their treatment goals (Onocko Campos et al., 2008).

With this objective, the GAM development initiative in Brazil was based on the multicenter pilot research, which deployed the first groups in 2007, coordinated by several Brazilian universities (Onocko Campos et al., 2008).

As a collectively implemented strategy, GAM entails that sharing experiences in a group generates co-management practices, resulting in joint decisions about treatment. The autonomous management aims to expand the possibilities of care collectively. Also, the more connected users, family, and healthcare team are to a care network, more possible ways of proper medication administration and management there are. Through dialogue between users and professionals, it is possible to assess how the use of medication is improving quality of life, reducing the suffering caused by disease symptoms, or, in contrast, increasing it with unwanted effects (Onocko Campos et al., 2014). In this respect, the mental health groups contribute to the rehabilitation of the suffering individuals, to their self-care, and can help them to deal with the experienced issues, such as daily social life, functions, and practices, hindered by a suffering background (Ribeiro, Marin, \& Silva, 2014).

It is known that GAM acts accordingly to each location, because health context, territory, teams, administration, culture, and social relations influence each studied dynamics. Studying the experience of participants in GAM is relevant because it accesses knowledge that allows altering relational practices whether with medication or the daily services.

Therefore, this study aims to examine the perceptions and effects of individuals' participation in GAM groups in a Brazilian psychosocial care 
center (CAPS). We intend, thus, to describe the experiences and the obstacles encountered by the team and the GAM group itself.

\section{Research Questions}

Does the GAM strategy improve the knowledge of users about medication? Has the group experience helped to empower these participants relating to decisions about their treatments? Have the teams facilitated or hindered this process?

\section{Methodology}

As the study focuses on the experience of individuals regarding their participation in the GAM group, this research became a qualitative study, since it sought to know the meanings of the participation experience in the GAM group. As an exploratory and descriptive study, it seeks to understand better and describe this phenomenon. This research was developed at the CAPS II Ponta do Coral belonging to the Municipality of Florianópolis, in Santa Catarina State, associated with the Health Municipal Office. We chose this service because it has already an established partnership with the university which promotes this research. Also, this CAPS is available to develop user empowerment strategies. Participants were six adults from the psychosocial care center indicated by the multidisciplinary team, having participated in the GAM group. These participants were diagnosed with mental disorder and used psychotropic drugs.

The inclusion criteria for participants of the study were: diagnosis of mental disorder with drug prescription for the last 6 months or more, participation in the GAM group, and able to answer the questions at the time of data collection. The exclusion criteria are individuals younger than 18 years old, indicated by professionals not belonging to the service, and experiencing a psychic crisis.

For the data collection, we used the structured interview as a research technique, with the topics: a) experience in participating in the GAM group and b) the effects of the group on participants' experience. In turn, the interviewer defined for each objective three or more sequential questions, to ultimately address the two main issues mentioned above. The interviews were previously scheduled by telephone and took place from December 2016 to January 2017. The participants were interviewed individually, for approximately 30 minutes each, in a silent and adequate room in the psychosocial care center, in compliance with the precepts of Resolution 466/2012 of the Brazilian National Health Council.

The study was approved by the Research Ethics Committee, according to the protocol no. $1,808,019$.

The data were collected using interviews, recorded them with a voice recorder, and subsequently transcribed and analyzed them. After transcribing the interviews, we analyzed them through critical and reflective interpretation and content analysis, following the steps recommended by Minayo (2008): sorting of data; initial categorization; re-sorting of empirical data and final analysis, organizing data according to the theoretical framework and the response to the research question based on the initial objectives. We discussed and analyzed the results based on the theoretical framework and practical reality.

The interviewees were identified with alpha-numeric codes in the descending order of the interviews, as shown in Table 1 . The anonymity of the participating institution was also preserved. The final number of interviewees was defined also preserved by saturation, totaling 6 participants. The methodology of choosing participants by saturation consists of suspending the inclusion of new participants when data present, from the researcher's perspective, redundancy or repetition, thus not being relevant to continue the data collection (Fontanella, Ricas, \& Turato, 2008). 
Table 1

Characterization of research participants

\begin{tabular}{|c|c|c|c|c|c|}
\hline Identification & Gender & $\begin{array}{l}\text { Duration of } \\
\text { treatment in } \\
\text { CAPS }\end{array}$ & $\begin{array}{l}\text { Marital } \\
\text { status }\end{array}$ & STP activities & Medication used \\
\hline P1 & Male & $\begin{array}{l}1 \text { year and } \\
10 \text { months }\end{array}$ & Single & $\begin{array}{l}\text { Multidisciplinary group; } \\
\text { Psychiatric consultation; } \\
\text { Collective space "I do } \\
\text { not live in me anymore"; } \\
\text { Gardening workshop }\end{array}$ & $\begin{array}{l}\text { Biperiden, haloperidol, li- } \\
\text { thium carbonate, carbamaze- } \\
\text { pine, chlorpromazine }\end{array}$ \\
\hline P2 & Male & 1 year & Single & $\begin{array}{l}\text { Multidisciplinary group; } \\
\text { Psychiatric consultation } \\
\text { Psychological care; }\end{array}$ & $\begin{array}{l}\text { Olanzapine, lithium carbona- } \\
\text { te, chlorpromazine }\end{array}$ \\
\hline $\mathrm{P} 3$ & Female & $\begin{array}{l}5 \text { years and } \\
3 \text { months }\end{array}$ & Single & $\begin{array}{l}\text { Multidisciplinary group; } \\
\text { Psychiatric consultation }\end{array}$ & $\begin{array}{l}\text { Biperiden, haloperidol, lithi- } \\
\text { um carbonate, promethazine, } \\
\text { chlorpromazine }\end{array}$ \\
\hline $\mathrm{P} 4$ & Male & $\begin{array}{l}2 \text { years and } \\
3 \text { months }\end{array}$ & Single & $\begin{array}{l}\text { Multidisciplinary group; } \\
\text { Psychological care; } \\
\text { Drawing workshop }\end{array}$ & $\begin{array}{l}\text { Valproic acid, haloperidol, } \\
\text { biperiden }\end{array}$ \\
\hline P5 & Female & $\begin{array}{l}2 \text { years and } \\
11 \text { months }\end{array}$ & Married & $\begin{array}{l}\text { Multidisciplinary group; } \\
\text { Psychiatric consultation; } \\
\text { Maria Bonita group; Cio } \\
\text { da Terra group }\end{array}$ & $\begin{array}{l}\text { Lithium carbonate, risperi- } \\
\text { done, biperiden, rohypnol }\end{array}$ \\
\hline P6 & Female & $\begin{array}{l}3 \text { years and } \\
8 \text { months }\end{array}$ & Married & $\begin{array}{l}\text { Multidisciplinary group; } \\
\text { Psychiatric consultation }\end{array}$ & Amitriptyline, diazepam \\
\hline
\end{tabular}

Note CAPS = Psychosocial Care Center; STP = Singular Therapeutic Project.

\section{Results and discussion}

Data analysis was based on the reading and interpretation of the content of the participants' interviews. As a result, two categories emerged, the first describing the context of the participants' experience in the GAM group and the second the effects of the group on users' experience.

\section{Context of participants' experience in the GAM group}

In the GAM group, participants were able to share experiences about medication in mental health and to reveal the reasons why they participated in the group, such as open dialogue, mutual listening, and respect for the unique experiences shared.

The GAM-BR guide is a practical instrument which assists in learning about the use of medication and its effects on individuals' lives through topics and issues contributing to the exchange of personal and collective experiences about medication within the group. I go home happy because we listen to the stories of others. How they take the medication or do not. If they take it, which one. We learn a lot! . . . We listen to each other. So that is awesome! I came here to learn more, right? And, at least, I'm trying to learn that screwing up isn't worth it. (P6, January 2017)

GAM understands that users have the right to information and with it they can adapt the treatment to their needs and, thus, they use the guide as a tool that provides information about medication and encourages them to reflect upon the treatment and related issues. In this respect, they will hopefully seek to know about and make decisions according to 
their needs and wishes relating to medication together with health professionals who assist them in a shared care building process (Onocko Campos et al., 2014).

The GAM-BR guide is comprised of two parts and six steps with various questions. In the first part, the questions are related to their quality of life: a) discovering yourself a little; b) observing yourself; c) extending your autonomy; d) talking about the psychiatric medication. Part two indicates a route for changes: e) where you go to; f) planning your actions. Addressing these topics allows sharing singular experiences, contributes to reflection, mutual aid, helps to seek information about medication and user rights. Consequently, individuals will participate in this process and discuss these issues with the professionals who assist them, thus contributing to remaking decisions about details of their treatment (Onocko Campos et al., 2013). Concerning group experiences, the factors that influenced the participation included curiosity and the will to learn about it.

Because I was curious. Because I'm a little curious. And then I stayed at home thinking 'oh, if I leave, I'll go to the group, so I'll talk and then I'll know. So I came. And it was very good too. Because when I was at home, I stayed in my room and felt depressed. (P4, January 2017)

The relation of individuals with the pursuit of knowledge requires spaces for curiosity stimulation so they can become in several ways persons willing to learn. In the GAM group, like in other spaces, individuals possess knowhow based on their life and suffering experiences, which only they can speak of. However, this know-how, usually known as common sense, needs to become knowledge that promotes change in people and stimulates criti$\mathrm{cal}$ and creative awareness of issues related to their treatment and their status as individuals with rights.

Concerning mental suffering experiences, lined by subjectivity and daily life injunctions and afflictions, individuals are the main producers of meanings and main contributors to their mental health. The group approach assists in choosing those meanings which make up the desire, as subjectivity uses language, as a symbol, for individuals to actively become human beings and interact with their peers (Costa-Rosa, 2013).

The GAM group dynamics, when dialogued and shared, encourages participants to talk about their history about the use of psychiatric medication, leading to a set of statements and meanings given by individuals to the experience, in addition to emphasizing other aspects related to their lives and treatments. In the following excerpt, the interviewee discusses the group experience by talking about what he/she feels when taking the medication. Using the robot metaphor, he/she reveals an act which becomes automatically natural: symptom, diagnosis, prescription, a result of an automatic circle, potentially causing decreased self-criticism due to the notion that medication is the most valuable treatment resource.

I was able to talk a lot about what I felt about medication. That I talked... That I couldn't accept... that I felt like a robot. And it's true. I think that not all cases need medication. Some cases need... a conversation. And the person doesn't need to be drugged. It's complicated. But, if we talk, it's different, right? Someone listens. They might agree or even disagree, and explain why, right? It goes back. These thoughts get in order. (P3, December 2016)

In the daily health services, talking about the experience of medication use is sometimes limited to dialogues including common complaints by users and therapeutic medication practices by professionals, that is, one talks about what they expect to listen to get what one wants, the medication. The group helps to extend this approach by encouraging participants to talk about of their experience, to reflect on the decisions, and to rely more on their experiences, potentialities, and resources to deal with the situations they face in life.

In line with the excerpt of the participant above, GAM proposes to place caregivers and users side by side, while co-managing care processes and mutually co-producing, so they can, using dialogue, make treatment decisions based on joint management. Thus, one can regard co-management as a strategy to empower and provide protagonism to differ- 
ent individuals (employees, managers, users, and families) involved in the process of health production. Indeed, when applied, this strategy creates appropriate conditions for different manifestations of autonomy (Passos, Palombini, et al., 2013).

Talking about the experience of taking psychiatric medication proved to be relevant to participants because they create a different relationship with their treatment and the use of psychiatric medication.

This group was extremely interesting to me. Sometimes I didn't want to come or had other engagements ... But I was interested in coming. Because every time I came here, if I learned two little sentences, it was good enough for me! So I didn't make the same mistake again, see? Like: taking too much medication or not taking it or taking less. Someone would say 'The medication your doctor gave you sucks. Take this one instead'. And I would take it. I was that bad, see? So it was a learning experience for me. (P6, January 2017)

Using leitmotif topics such as reflecting upon oneself, one's daily activities, one's relationships, the effects of medications in one's life, the support network, and the rights of who performs the treatment, GAM allows creating new relationships between users and the health team, subjectively reorganized amongst themselves, based on shared care and the construction of a collective autonomy. As a result, there is a transaction of different know-how and world perspectives inside the network of relationships between users and health professionals, which require public democratic and political conditions, as well as the access of individuals to information and their ability to evaluate it (Santos, 2014; Passos, Otanari, Emerich, \& Guerini, 2013).

GAM contributes to the democratization of health services and the better care quality, for a health education which enables reflection between users, professionals, and families (Onocko Campos et al., 2014). Through dialogue, considering individuals in their critical speech, not as an object of their own speech, but as an entity capable of debate and commitment, engaged in a social, political, and empathetic responsibility, they can understand the subjectivities and strengthen their awareness about themselves and their reality (Prado \& Schmidt, 2016).

The GAM group has stimulated an environment which encourages the participants' critical sense, for instance, regarding which speech to adopt when addressing the use of medication as the only resource for dealing with suffering and the awareness of the need for other therapeutic tools in this process.

I cleared doubts about some drugs. Especially haldol. The one that harmed me the most ... It's effective for some people . . . improves their lives. Not so much for others. One must pay attention to these cases. For some, it's not the medication that matters, just the psychology. (P3, December 2016)

Participants state that some attitudes impact the quality of life besides the use of medication. Also, they describe a health concept in which the human being's complexity and a comprehensive and singular approach can improve mental health.

I know medication acts on your body, it calms you down. For sure. I've been taking it for ten years. It really calms you down. It's not a cure though, and medication isn't enough. You need to have someone to talk to! You have to scream, you have to take a shower, you have to walk, you have to do something! (P6, January 2017)

Due to the participation in the group, individuals understood that knowledge about medication does not belong only to the prescriber. Reports show that the GAM group allowed them to learn about other treatment possibilities, such as the importance of seeking information to make choices that benefit their treatment.

Based on the statements in the interviews, we note that the relationship participants established with professionals impacted the bargaining power and the interest in knowing and deciding on the most appropriate medication. Moreover, the interviewees described the constraints related to the experience of taking psychiatric medication, like the difficulty in dealing with side effects, as well as 
the mental disorder stigma associated with its usage. These situations complicate the discussion about taking medication because of physical, psychological, historical, and social limitations.

"So, you realize the medication, everything you feel in your body, this whole thing, it impacts you negatively. You cannot write correctly, cannot speak what you're thinking." (P3, December 2016).

About the use of medication, the experiences with psychotropic drugs were often diverse, involving drowsiness, altered reality perception, and psychomotor retardation. Some interviewees regard these experiences as something terrifying, so facing the stressors related to the use of psychiatric medication can impact users more than the medication effects. (Jorge, Onocko Campos, Pinto, \& Vasconcelos, 2012).

Effects of the autonomous medication management group in participants' experience

The group was for the participants a space to talk about what they thought and felt. Their involvement in the group impacted the dynamics and relationships between them. The research participants stated it was important being heard, exchanging experiences, and having their subjectivity acknowledged.

The chance to be heard, the fact that people care, validate what you say, is worth it. As I said earlier, these people have the chance to confide in someone, talk about it. (P2, December 2016)

Participants felt more at ease to talk since their opinion is not usually taken into account in some situations. When labeled mad, they end up being regarded as incapable or using a type of speech associated with the characteristics of madness (Ramos, 2012). Sometimes, they struggle to talk, due to the fear that individuals do not understand each other. In everyday health services, the relationship between users and professional is usually based on speeches that are not listened to, and prescribing medication can be seen by individuals as recognition for their suffering. What should be talked about and heard falls prey to a medication-based practice, aimed at identifying symptoms to build up a diagnosis, without taking into account how users deal with suffering daily. The solution for these situations would be creating opportunities for humanized care not limited only to medication treatment, even if some users seek it. This humanized care must allow individuals to be more participative, thus contributing to their bargaining power in situations related to their life and treatment.

Acknowledging the singular dimension of individuals is crucial to welcome, listen to, and develop subjective processes. These should include the "production of the individuals in their relationship with the world, thus subjectivizing reality, continuously based on life experiences, not only actions carried out in the current moment, but also the meanings historically set up in individuals" (Mori \& Rey, 2012 , p. 145). The collective, as it is understood, reveals itself to be an element capable of promoting a kind of participation which, instead of reinforcing the signs of growing individualism in an exclusionary society, can ensure the possibility of any individual, at any given time, to be the first to impose him/herself as protagonist (Costa \& Paulon, 2012).

In the following narrative, the feeling of being important is proof of the empowerment the GAM group provides to participants.

It was different. Yes. It was a different phase of my life. Because I learned things, and I shared things, something different that I did not know about. It was good also because I felt more important. I learned about the medication, what happened when I took it. What my companions talked about and what I talked about. Because we reveal our experiences. (P4, January 2017)

Participation in the group led to reflecting upon themselves and their own decisions. GAM believes that participants, through dialogue and reflection upon it, begin autonomy processes and the leadership of their care, aiming at recovering the citizenship and rights of people who use psychotropic drugs (Passos, Palombini, et al., 2013). In any case, users' participation in transaction spaces, as GAM aims to talk about what happens in relationships, requires a process in which individuals 
allow themselves to think about their role in the relationship with others. The GAM guide encourages participants to talk about the need for a mental health service, the symptoms each one has, and how they deal with these demands, associating them with a care project. The link between life history, suffering, illness, and medication use occurs singularly when users talk (Marques, Palombini, \& Campos, 2013).

We note that the access to information and talking about medication provided subjective perceptions and awareness about what is their responsibility. Also, it allowed them to consider the group as a place of mutual help.

When I fell like doing something regarding medication, I think about you, and I just don't do it, right? I think it gave me self-help. Thinking about you, the group, the book itself, medication, everything, right? It helps me in a way so that ... it doesn't let me ... If I really focus on what I didn't focus properly, that will help me further. (P6, January 2017)

The experience in the GAM group had a therapeutic bonding effect; the place the group can occupy in the person's subjectivity and act as a contingency tool in extreme situations. Therefore, it is necessary to explore situations the group can update in the users' mental process. Another effect of the GAM group was that, with homework, families and close friends of participants were able to familiarize with what was going on. Next, a participant reports a family experience influenced by the experience in the group.

Yesterday, my daughter took the book to read it. You won't be going anymore, mom? You've been missing a lot. (laughs). She came here before. She asked: Who cares for them? She found it (the GAM guide) in the backpack. She read it and said: What's this, mom? I said It's from the CAPS'. She asked: What is the GAM? And I said Actually, Im not sure what it is (laughs). It was in the beginning; she already knew about it. So I said It's where I learn how to deal with my medication. Oh, so let's see it so you don't get sick anymore. (P5,
January 2017)

This testimony showed the power of the GAM guide as an instrument to raise awareness in who is not directly involved with the possibility of another care production. So, the GAM guide acts as a device that affects and stimulates dialogues from the moment that families or caregivers begin to understand, from another perspective, the complexity of the life of a person undergoing mental health treatment. The closest family relationships can, or cannot, improve since the GAM guide can trigger empathy in who has access to the literature.

The bond between people, within the context of mental health, whether user-user, user-professional, user-professional-family, brings new meanings to the care and attention relationships, and promotes the construction of autonomy based on shared accountability and agreed between those involved.

We make friends! Friendship is so important. Even if we made just one friend, it was worth it. If we made a lot, even better! I think that, when people gather in a group, they make friends. (P1, December 2016)

The concept of friendship resonates with the GAM process because the group consists of a gathering of people who create a bond between them through the reporting of their stories. In the relationships of respect, conversation, and listening that we establish with people, it is possible to mitigate what generates suffering and to further promote well-being, using collective attitudes that encourage the creativity of life and the reconstruction of a better everyday life.

\section{Conclusion}

During the GAM experience, participants confirmed the characteristics identified in several other studies about this health practice format. The group provided a significant experience as a space to talk about the experience with psychiatric medication; being heard; listening to others; and learning about medication with the information provided by the group and the GAM guide. This confirmation reinforces the notion that practices 
which place individuals at the center of the process are crucial to empower and improve the autonomy of people with mental health disorders.

Also, the GAM strategy reinforced the affirmation of the participants' subjectivity, prioritized their participation and protagonism in every speech, urged critical reflection based on dialogue, and led to the development of bonds and new perceptions about the treatment and themselves. The participants stated their experience in talking about psychiatric medication impacted their therapeutic process, and the use and discussion of information provided by the GAM guide improved their learning and knowledge about medication.

Concerning the study's limitations, it was not possible, in the analyzed period of participation in the GAM groups, to determine if all the changes occurred in the narratives were exclusively associated with the experiences of the GAM strategy, since many aspects related to their lives and their therapies affected them simultaneously. Moreover, we keep in mind that these are reflections and perceptions from their perspective, which were not compared to those of family members or professionals who assist them.

Thus, GAM emerges in the current panorama, where health services still provide forms of care sometimes centered in diagnostics and medication that exclude the user's knowledge, as an approach capable of implementing horizontal relationships to build new forms of care, to promote the route of listening and speech, of health education, psychosocial support, and bond. It is a method for care reform, so that diagnosis, disease, and drug prescription are no longer the main concerns. As a result, users, instead of being dependent on the relationship with the service, can get the appropriate conditions to use the service to reclaim their place as citizens.

\section{References}

Barrio, L. R., Campos, R. O., Stefanello, S., Santos, D. V., Cyr, C., Benisty, L., \& Otanari, T. C. (2014). Human rights and the use of psychiatric medication. Journal of Public Mental Health,
13(4), 179-188. doi:10.1108/JPMH-06-20130039

Costa, D. F., \& Paulon, S. M. (2012). Participação social e protagonismo em saúde mental: A insurgência de um coletivo. Saúde em Debate, 36(95), 572-582. doi:10.1590/S0103-11042012000400009

Costa-Rosa, A. (2013). Atenção psicossocial além da reforma psiquiátrica: Contribuiçóes a uma clínica critica dos processos de subjetivação na saúde coletiva. São Paulo, Brasil: Unesp. Retrieved from http:// editoraunesp.com.br/catalogo/9788539304813,atencao-psicossocial-alem-da-reforma-psiquiatrica

Fontanella, B. J., Ricas, J., \& Turato, E. R. (2008). Amostragem por saturação em pesquisas qualitativas em saúde: Contribuiçôes teóricas. Cadernos de Saúde Pública, 24(1), 17-27. doi:10.1590/S0102311X2008000100003

Jorge, M. S., Onocko Campos, R., Pinto, A. G., \& Vasconcelos, M. G. (2012). Experiências com a gestão autônoma da medicação: Narrativa de usuários de saúde mental no encontro dos grupos focais em centros de atenção psicossocial. Physis: Revista de Saúde Coletiva, 22(4), 1543-1561. doi:10.1590/ S0103-73312012000400015

Marques, C. C., Palombini, A., \& Campos, R. T. (2013). Sobre mudar de lugar e produzir diferenças: A voz dos usuários de serviços públicos de saúde mental. Mnemosine, 9(1), 106-126. Retrieved from http://www.fcm.unicamp.br/fcm/sites/default/ files/paganex/cecilia2013sobremudardelugar.pdf

Minayo, M. C. (2008). O desafio do conhecimento (11 a ed.). São Paulo, Brasil: Hucitec.

Mori, V. D., \& Rey, F. G. (2012). A saúde como processo subjetivo: Uma reflexão necessária. Psicologia: Teoria e Prática, 14(3), 140-152. Retrieved from http://pepsic.bvsalud.org/scielo.php?script $=$ sci_arttext $\&$ pi$\mathrm{d}=$ S1516-36872012000300012\&lng=pt\&nrm=iso

Onocko Campos, R. T., Palombini, A. L., Passos, E., Gonçalves, L. L., Santos, D. V., Melo, S. S., ... Guerini, L. (2014). Gestão autônoma da medicaçâo: Guia de apoio a moderadores. Retrieved from https://www.fcm.unicamp.br/fcm/sites/default/ files/paganex/guia_gam_moderador_-_versao_ para_download_julho_2014.pdf

Onocko Campos, R. T., Passos, E., Leal, E., Palombini, A. L., Serpa, O., Marques, C. C., ... Zanchet, L. (2008). Pesquisa avaliativa de saúde mental: Instrumentos para a utilização de psicofármacos e formação de recursos humanos. Campinas, Brasil: Universidade Estadual de Campinas.

Onocko Campos, R. T, Passos, E., Palombini, A. L, 
Santos, D. V., Stefanello, S., Gonçalves, L. L. M., ... Borges, L. R. (2013). A gestão autônoma da medicação: Uma intervenção analisadora de serviços em saúde mental. Ciência \& Saúde Coletiva, 18(10), 2889-2898. doi:10.1590/S141381232013001000013

Passos, E., Palombini, A. L., Onocko Campos, R. T., Rodrigues, S. E., Melo, J., Maggi, P. M., ... Emerich, B. (2013). Autonomia e cogestão na prática em saúde mental: $\mathrm{O}$ dispositivo da gestão autônoma da medicação. Aletheia, 41, 24-38. Retrieved from http://pepsic.bvsalud.org/pdf/aletheia/n41/ n41a03.pdf

Passos, E., Otanari, T. M., Emerich, B., \& Guerini, L. (2013). O comitê cidadão como estratégia cogestiva em uma pesquisa participativa no campo da saúde mental. Ciência \& Saúde Coletiva, 18(10), 29192928. doi:10.1590/S1413-81232013001000016

Prado, M. L., \& Schmidt, R. K. (Orgs.). (2016). Paulo Freire: A boniteza de ensinar e aprender na saúde. Florianópolis, Brasil: Universidade Federal de Santa
Catarina. doi:10.5902/2179769225213

Ramos, J. F. (2012). A autonomia como um problema: Uma pesquisa a partir da realização do dispositivo GAM em um CAPS fluminense (Master's Dissertation). Universidade Federal Fluminense, Instituto de Ciências Humanas e Filosofia, Departamento de Psicologia. Retrieved from c

Ribeiro, L. A., Marin, L. L., \& Silva, M. T. (2014). Atividades grupais em saúde mental. Revista Baiana de Enfermagem, 28(3), 283-293. Retrieved from https://portalseer.ufba.br/index.php/enfermagem/ article/view/9980/8990

Santos, D. V. (2014). A gestão autônoma da medicação: Da prescrição à escuta (Ph.D.'s Thesis). Universidade Estadual de Campinas, Brasil.

Yasui, S., \& Costa-Rosa, A. (2008). A estratégia atenção psicossocial: Desafio na prática dos novos dispositivos de saúde mental. Saúde em Debate, 32(78-80), 22-37. Retrieved from http://www.redalyc.org/articulo.oa?id=406341773003 